\title{
MINING TRENDS AND THE POTENTIAL SPATIAL DEGRADATION IN THE EAST PLANNING REGION IN REPUBLIC OF MACEDONIA
}

DOI: http://dx.doi.org/10.18509/GBP.2018.53

UDC: 502.15:622.2.012(497.7)

\author{
Hristina Odzaklieska ${ }^{1}$ \\ Lidija Trpenoska ${ }^{1}$ \\ Olgica Dimitrovska ${ }^{2}$ \\ ${ }^{1}$ Spatial Planning Agency, Skopje, Republic of Macedonia \\ ${ }^{2}$ Institute of geography, Faculty of science, University "Ss. Cyril and Methodius", Skopje, \\ Republic of Macedonia
}

\begin{abstract}
The East planning region of the Republic of Macedonia has a great mining history. As a result, there is a great quantity of waste and significant impact on the environment. Lately the region is facing a trend of opening new mines, that will affect the economic and social activities in the region. The increased impact on the environment and the lack of positive remediation experiences were the motive for analysis of the correlation between proposed mining activities and environmental protection.

The analysis consists of confronting the value of the locations (natural heritage, settlements, hydrological elements) and the impact on the environmental media.

The analysis showed that only several locations may be exploited without major spatial degradation consequences.
\end{abstract}

Keywords: spatial planning, environment, mining, pollution

\section{INTRODUCTION}

The environmental protection in the past was not as important as the economic benefit of the industry. The outdated technologies used in most of the capacities over time resulted in 16 contaminated sites around the country, where the presence of soil contamination is well recognized [6]. The seriousness of possible effects on the ecosystems and people's health is such that remedial measures are required. Although there is some progress in the maintenance of the contaminated sites, after all these years none has been totally remediated, according to the environmental indicators of the Ministry of environmental and physical planning. The analysis of the type of the contaminated sites show that there are 5 mines among them [3].

The East planning region (EPR) in the Republic of Macedonia has a great mining history. As a result, $99,98 \%$ of the waste generated from the mining industry and stone extraction is concentrated in the East planning region, which has had enormous negative environmental impact [13]. Lately, the region is facing a trend of opening new mining sites, that will affect the economic and social activities in the region, as well the environmental values. This paper is analyzing the potential impact on the spatial values from the planned concession sites, especially from environmental and social viewpoint. 


\section{AIMS AND OBJECTIVES}

The main aim of the paper is to offer sustainable approach through the process of location selection for a geological research concession site, with minimal environmental and social impact, having in mind that these sites later, become exploitation fields.

The objectives of the paper are:

- Analysis of the locations given as concession sites for geological research in the EPR;

- Environmental aspects of the national legal framework regarding the selected locations;

- Suggested sustainable approach for the best possible location selection for mining activities with minimum environmental impact.

\section{THEORETRICAL BACKGROUND}

Water quantities for the needs of industry and mining sector in the Republic of Macedonia are mostly provided from surface waters (watercourses, reservoirs and lakes). The use of water from springs, needed for supply in the industry and mining sector has risen from $8 \%$ in 2010 up to $51 \%$ in 2015 . The underground water remains the least used source for water supply in the industry and mining sector with around 1-2\% [2]. Comparing to other regions in the country, the East planning region has major water use in the industry and mining sector [7].

The national statistical data show that less than $1 \%$ of the wastewater generated in the industry and mining sector is treated before it is discharged [2]. Furthermore, almost the whole untreated wastewater form industry and mining sector in 2015 was discharged in the watercourses, reservoirs and the soil $(99,6 \%)$. Less than $1 \%$ was discharged in the public sewers. Comparing to other regions, the greatest share of the unpurified wastewater from the industry and mining sectors is discharged in the East planning region [7].

The current water protection issues against pollution in industry and mining and the amount of waste generated from the mining industry in the East Planning Region, as well as the present natural values, were the motive for the research analysis presented in this paper.

\section{METHODOLOGY}

The qualitative methodological approach was used for the assessment of the spatial potential of the selected locations. The concession sites were analyzed through several criteria: the distance from the surrounding populated areas, nearby natural heritage, environmentally polluted areas and existing nearby water basins. The collected data, organized in a geodatabase, using a GIS methodology and tools, were then used for the analysis, which resulted in several important points presented in the conclusion of the research paper.

\section{STUDY REGION}

The East Planning Region, determined according to the nomenclature of the territorial units for statistics NUTS-3 [8], is in the eastern part of the Republic of Macedonia. It is bordered by the Vardar, Northeast and the South-East Planning Regions. It mainly covers the catchment area of the river Bregalnica and covers $13.76 \%$ of the territory of the Republic of Macedonia. 


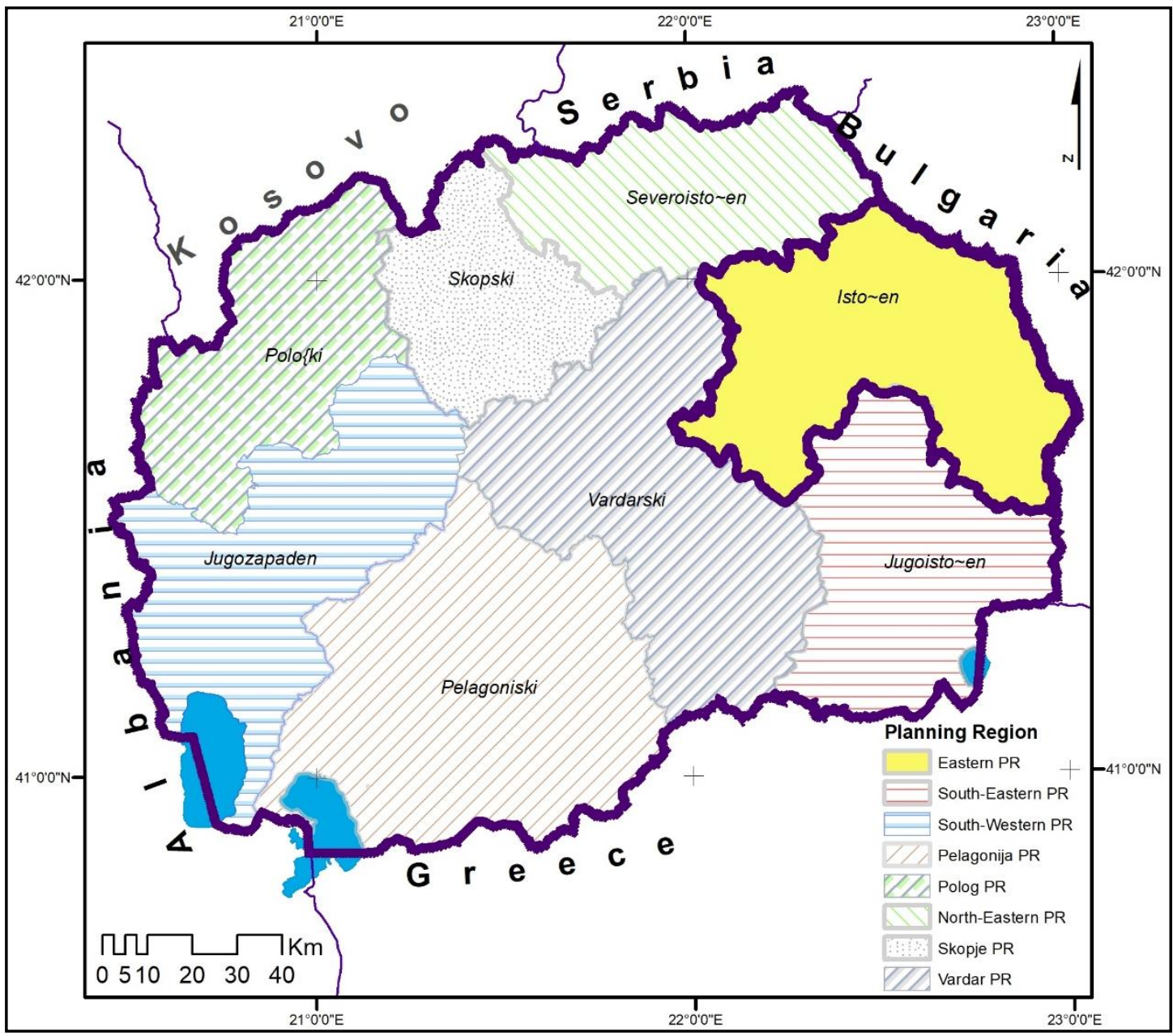

Figure 10. Statistical Planning Regions in the Republic of Macedonia with the position of the study region (East Planning Region)

The EPR is comprised of 11 municipalities: Berovo, Pehchevo, Delchevo, Kochani, Makedonska Kamenica, Vinica, Zrnovci, Probishtip, Cheshinovo-Obleshevo, Karbinci and Shtip, with a total area of 353,813.82 $\mathrm{ha}$. The number of settlements is 217, of which 8 are urban settlements and 209 are rural. Regarding the total number of settlements in the country, the Region participates with $12 \%$, and in the total number of the population with $9 \%$.

\section{Geologic-petrographic characteristics}

The geological structure of Eastern Macedonia includes rocks of metamorphic and complex Rhodope type, consisting of rocks of varying degrees of crystallinity-crystalline shales, Mesozoic and Tertiary sediments, magmatic and quaternary formations [1]. These rock masses are included in the following geological formations:

- Complex of Precambrian metamorphic rocks;

- Complex of old Paleozoic rocks and magmatites;

- Hercic-young Paleozoic magmatic rocks and sediments;

- Mesozoic sedimentary rocks and magmatites;

- Sedimentary rocks and volcanics of Tertiary and

- Quarter rocks and volcanics. 
The main characteristic of this area is its location in two geotectonic units on the Balkan Peninsula: the Serbian-Macedonian mass and the Vardar zone, each of which is characterized by its specific geological structure.

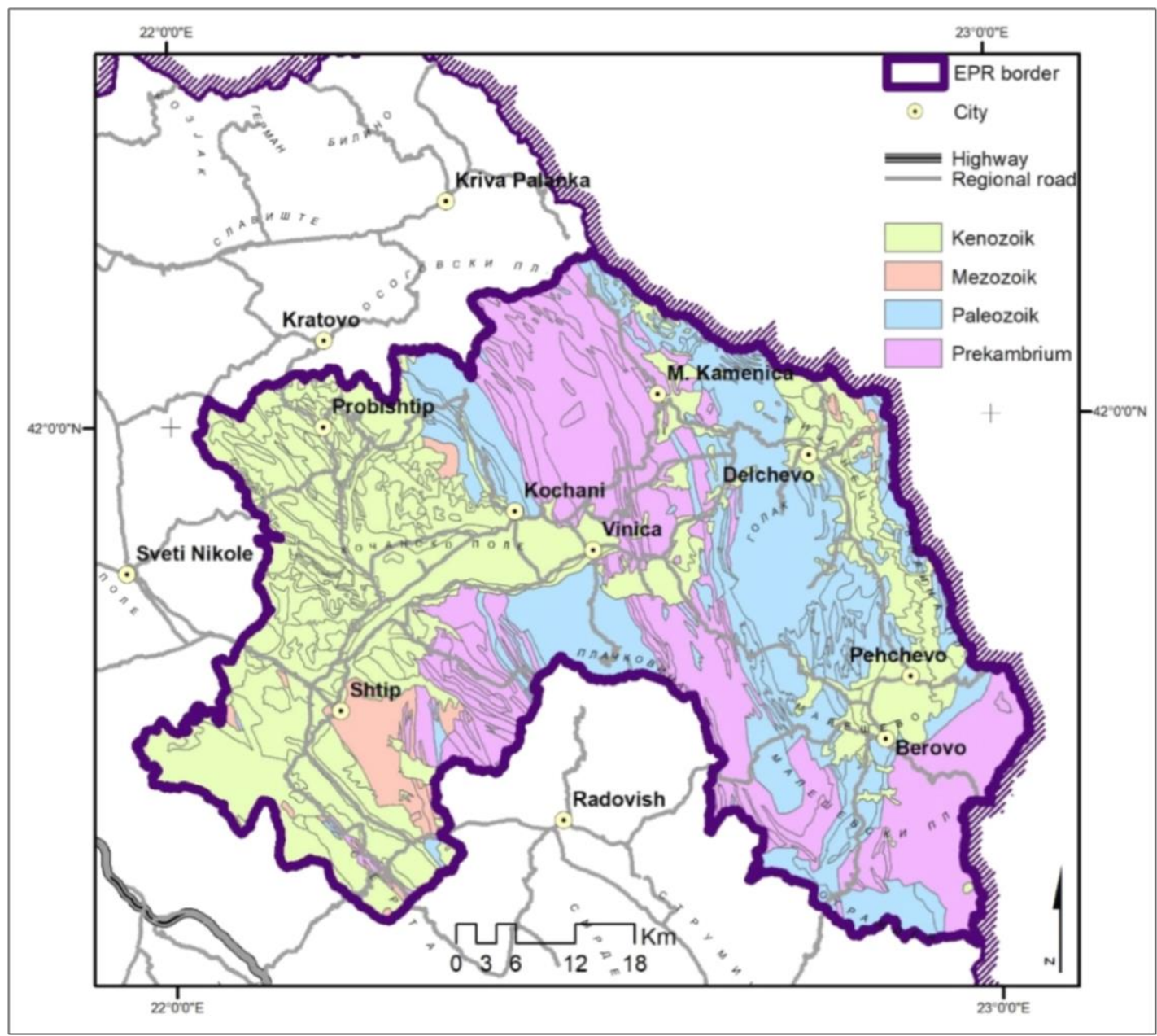

Figure 11. Geological formations

\section{MINING IN THE STUDY REGION}

Exploitation of mineral raw materials is regulated by issuing concessions. Concessions are issued for the exploration of mines and mining. Metallic, non-metallic, energy mineral resources, as well as water and geothermal water sources are found in the East Planning Region [1].

Table 1. Number of localities in EPR by type of mineral and status

\begin{tabular}{|l|r|r|r|}
\hline Type of mineral & \multicolumn{1}{|c|}{ Exploitation } & \multicolumn{1}{|c|}{ Research } & \multicolumn{1}{c|}{ Grand Total } \\
\hline Energy & 2 & 1 & 3 \\
\hline Metallic & 4 & 8 & 12 \\
\hline Non-metallic & 31 & 10 & 41 \\
\hline Water & 6 & 3 & 9 \\
\hline Grand Total & $\mathbf{4 3}$ & $\mathbf{2 2}$ & $\mathbf{6 5}$ \\
\hline
\end{tabular}




\section{Metallic mineral resources}

Metallic mineral resources represent the most significant resource and have a direct impact on the overall economic picture of the region. This is due to the presence of significant metallogenetic zones within which several major sites (mines) for $\mathrm{Pb}, \mathrm{Zn}, \mathrm{Cu}$ and $A u$ are determined.

From the existing concessions for exploitation of metallic mineral resources, the most significant, from the economic point of view, are the sites (mines): "Sasa" - Municipality of Makedonska Kamenica, "Dobrevo" and "Plavica" - Municipality of Probishtip. Of these mines, opened during the sixties and seventies in the last century, active exploitation is done in Dobrevo and Sasa, while in the "Plavica" additional geological explorations are ongoing for determining additional ore reserves and re-starting the mine.

\section{Energy minerals}

Regarding the representation of energy mineral resources, significant zones in the Region are: Probistip basin and Berovo-Pehchevo-Delcevo basin.

\section{Technogenic mineral resources}

These mineral resources are in fact raw materials that can be used in the process of exploitation of the primary mineral resource.

Also, as a technogenic mineral resource, part of the slag from the mines for metallic mineral raw materials can be used, where with new techniques and technologies additional extraction of the remaining content of metal in the slag is possible.

\section{Non-metallic mineral raw materials}

Significant are the occurrences of construction-technical stone, quartz, clay, opal breccia and tuff.

As subclass of the non-metallic mineral raw materials architectural-ornamental and architectural-construction stones are represented by: ignimbrites, limestones, andesites, sandstones etc.

\section{Water}

There are findings of mineral, thermo-mineral, thermal and mineral/ $/ \mathrm{CO}_{2}$ gas waters in the EPR. From the aspect of hydrothermal zoning, the following zones are distinguished: Kocani valley - Kocani-Istibanja, near the village Krupiste; granite massif in the surroundings of Stip (Stip granites) - the Kezhovica bath in the Stip area. 


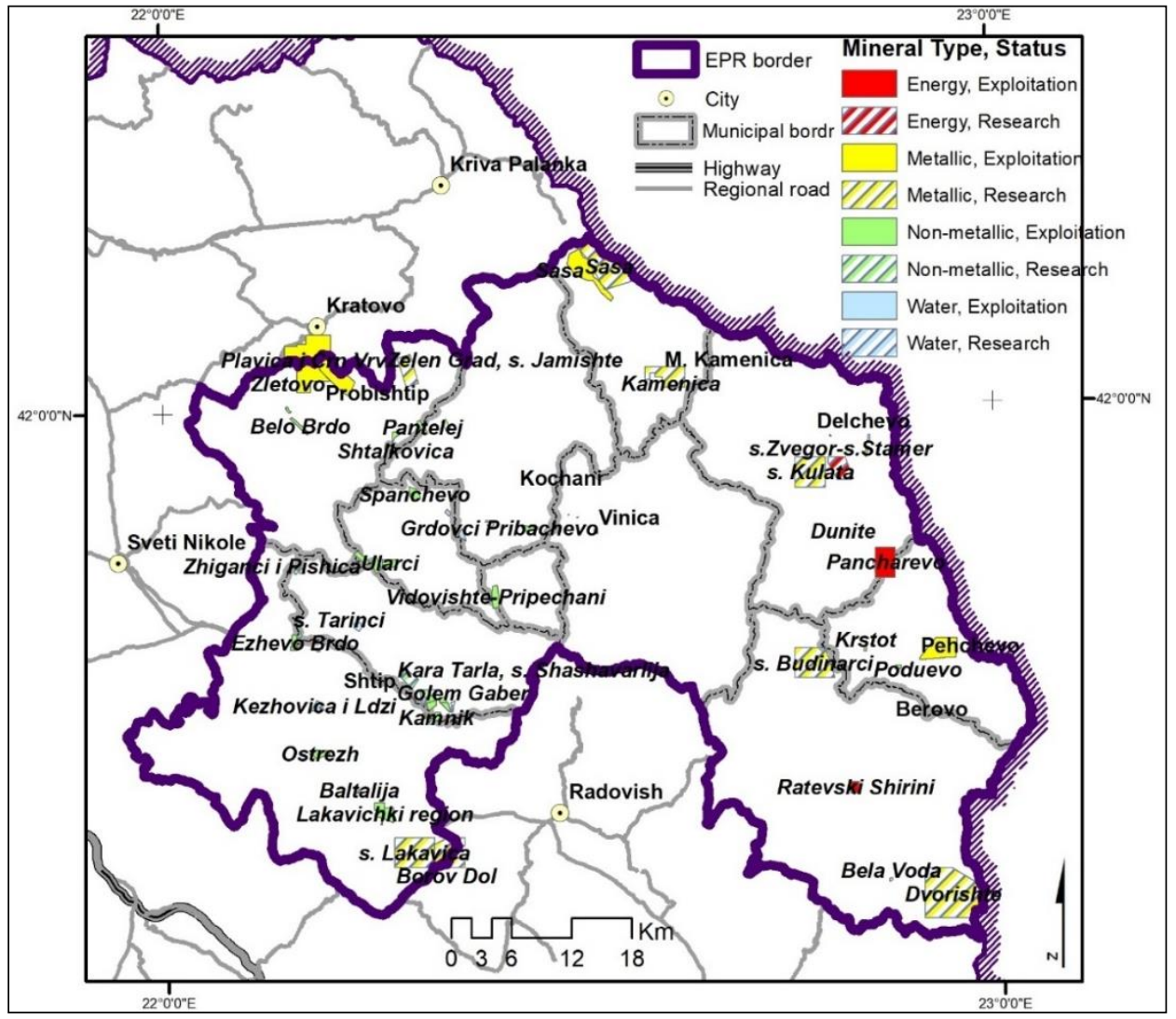

Figure 12. Localities with mining and research concessions, by mineral type

Table 2. Exploitation of minerals by type in the region (Area in hectares)

\begin{tabular}{|c|c|c|c|c|c|}
\hline 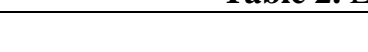 & \multicolumn{4}{|c|}{ Type of the mineral } & \\
\hline Mineral & Energy & Metallic & Non-metallic & Water & Exploitation Total \\
\hline Basalt & & & 82.30 & & 82.30 \\
\hline Ceramic Clay & & & 341.62 & & 341.62 \\
\hline Clay & & & 26.89 & & 26.89 \\
\hline Coal & 689.10 & & & & 689.10 \\
\hline Copper & & 600.67 & & & 600.67 \\
\hline Copper, Gold and Silver & & $1,688.18$ & & & $1,688.18$ \\
\hline Gabbro & & & 53.18 & & 53.18 \\
\hline Geothermal water & & & & 59.97 & 59.97 \\
\hline Groundwater & & & & 0.27 & 0.27 \\
\hline Lead & & 595.50 & & & 595.50 \\
\hline Lead and zinc & & 642.30 & & & 642.30 \\
\hline Limestone & & & 214.53 & & 214.53 \\
\hline $\begin{array}{l}\text { Limestone and Rapeseed } \\
\text { Limestone }\end{array}$ & & & 90.20 & & 90.20 \\
\hline Marble limestone & & & 12.35 & & 12.35 \\
\hline Opal Breccia & & & 98.24 & & 98.24 \\
\hline Quartz & & & 373.47 & & 373.47 \\
\hline Quartzites & & & 16.39 & & 16.39 \\
\hline Rapeseed limestone & & & 76.31 & & 76.31 \\
\hline Sand and Gravel & & & 6.53 & & 6.53 \\
\hline Slate & & & 42.50 & & 42.50 \\
\hline Thermo-mineral water & & & & 93.19 & 93.19 \\
\hline Tuff & & & 60.31 & & 60.31 \\
\hline Tuff, Gabbro, Monzonite & & & 42.50 & & 42.50 \\
\hline Grand Total & 689.10 & $3,526.64$ & $1,537.32$ & 153.43 & $5,906.49$ \\
\hline
\end{tabular}


Table 3. Research of minerals by type in the region (Area in hectares)

\begin{tabular}{|l|r|r|r|r|r|}
\hline \multicolumn{5}{|c|}{ Type of the mineral } \\
\hline Mineral & Energy & Metallic & Non-metallic & Water & Research Total \\
\hline Andesite & & & 35.17 & & 35.17 \\
\hline Basalt & & & 14.30 & & 14.30 \\
\hline Coal & 403.59 & & & & 403.59 \\
\hline Copper & & 769.40 & & & 769.40 \\
\hline Copper and gold & & $2,837.72$ & & & 5.72 \\
\hline Geothermal water & & & & 55.24 & 55.24 \\
\hline Groundwater & & & & 7.39 & 7.39 \\
\hline Limestone & & & 312.64 & & 312.64 \\
\hline Metallic & & $5,032.39$ & & & $5,032.39$ \\
\hline Quartz & & & 46.64 & & 46.64 \\
\hline Sand & & & 1.94 & & 1.94 \\
\hline Slate & & & 31.67 & & 31.67 \\
\hline Grand Total & $\mathbf{4 0 3 . 5 9}$ & $\mathbf{8 , 6 3 9 . 5 1}$ & $\mathbf{4 4 2 . 3 6}$ & $\mathbf{6 2 . 6 3}$ & $\mathbf{9 , 5 4 8 . 0 8}$ \\
\hline
\end{tabular}

The largest share in the areas intended for exploitation and exploration of mineral resources have metallic minerals $(79 \%)$, followed by non-metallic $(13 \%)$, energy $(7 \%)$ and water $(1 \%)$. The exploitation of the metallic ore is underground, but the impact of the technology used for exploitation on the environment is significant. Non-metallic minerals are extracted in quarries; therefore, the impact is mainly on the landscape and air quality. Water exploitation has the least visible impact on the environment. Still care must be taken regarding the long-term balance of underground waters in the Region.

\section{SUSTAINABLE APPROACH}

The process of sustainable spatial planning is essential for determination of the best possible use of the land use categories in the future. Thus, there is need to view the spatial potential from all aspects, before making a decision for future development of the planned area. The fact that some spheres of interest are forced towards rapid use without taking into account the spatial potential of the other spheres of interest is unsustainable.

The locations of the concession sites for geological research in this paper were analysed by their spatial potential through four criteria: populated areas, natural heritage, environmental values and water sources.

The distance between the concession site and the populated areas is very important since the geological research, and later the exploitation, will have environmental consequences which may result in health issues of the nearby population. Thus the nearby population will be mostly affected.

The second criterion was: the presence of nearby water bodies, since the mining activities will affect the life in them; the planned water supply systems, which will affect the population health through the quality of the drinking water and the planned irrigation systems, which will affect the nearby agricultural land, and consequently the population that will consume those products.

The third criterion was the distance from the natural heritage. The concession sites located in protected or proposed for protection natural heritage will affect the natural values in a long term, so the heritage will lose its designated values.

The distance from waste disposal sites is also important, since there might be indications for pollution of the underground water designated for exploitation. 
The outcome from the analysis of the concession sites for geological research in the East Planning Region, by these criteria is presented for each municipality below:

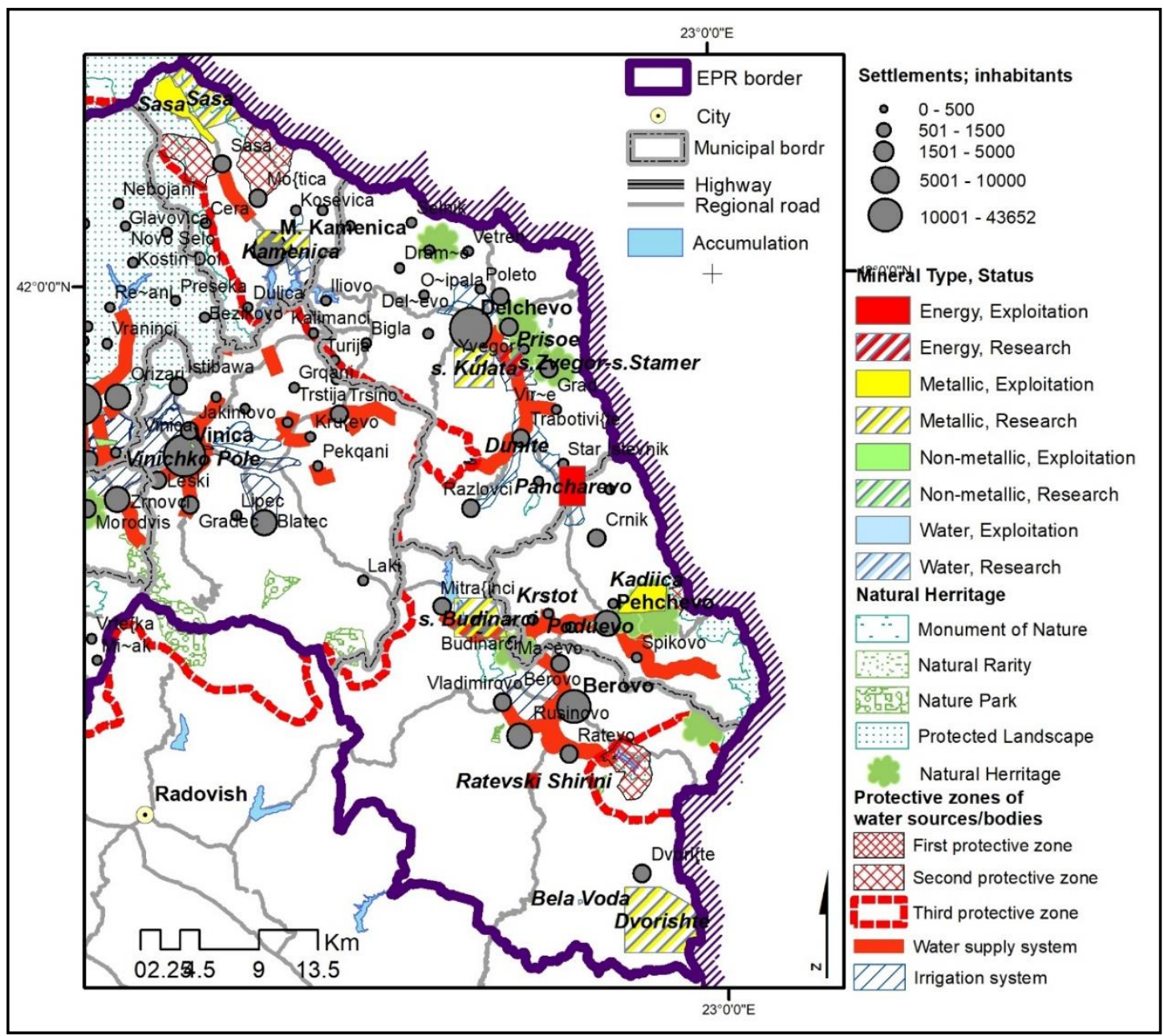

Figure 13. Localities with mining and research concessions in municipalities of Berovo, Pehchevo, Delchevo, M. Kamenica and Vinica

Table 4. Spatial potential of the concession sites for geological research in municipality of Berovo

\begin{tabular}{|c|c|c|}
\hline Research site & \multicolumn{2}{|r|}{ Spatial potential } \\
\hline \multirow{4}{*}{ 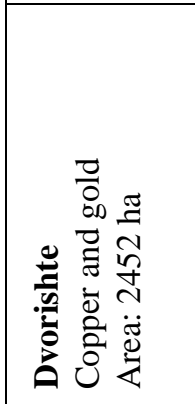 } & Populated area & $\begin{array}{l}\text { The concession site is located near the national border with Republic of } \\
\text { Bulgaria. } \\
\text { Nearest populated area in the Republic of Macedonia is Dvoriste, located } \\
\text { less than } 1 \mathrm{~km} \text { from the concession site. }\end{array}$ \\
\hline & Surfac & $\begin{array}{l}\text { There are several watercourses and flows crossing through the } \\
\text { concession site: Bukovkracka River, Sredocka River, Elenska River, } \\
\text { Crkvicka River and Zabelski, Gramadnicki and Drshanskiflow. }\end{array}$ \\
\hline & & $\begin{array}{l}\text { The concession site is located in representative area Ograzden proposed } \\
\text { to be managed for species conservation. }\end{array}$ \\
\hline & Environn & ld dump is located $0,7 \mathrm{~km}$ from the concession site. \\
\hline
\end{tabular}




\begin{tabular}{|c|c|c|}
\hline \multirow{3}{*}{ 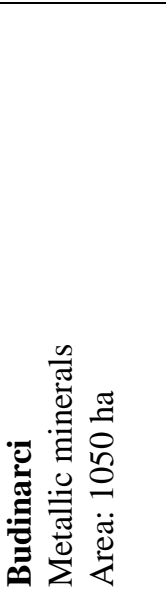 } & Populated area & $\begin{array}{l}\text { The concession site is partialy entering the populated area Budinarci. } \\
\text { The populated area Machevo is located at } 0,4 \mathrm{~km} \text { distance from the } \\
\text { concession site. } \\
\text { The populated area Mitrashinci is located } 0,75 \mathrm{~km} \text { from the concession } \\
\text { site. }\end{array}$ \\
\hline & Surface water & $\begin{array}{l}\text { Water supply sistem is located in the borders of the concession site. } \\
\text { There are several watercourses crossing through the concession site: } \\
\text { Bregalnica, Davalica, Kamenica, Golem Dol, Lenishka River, Roshul } \\
\text { and Selska River. } \\
\text { The concession site is partialy entering in the planned accumulation } \\
\text { Razlovci. } \\
\text { The irrigation system Ratevska Reka and Chiflic is located on } 0,8 \mathrm{~km} \\
\text { distance from the concession site. }\end{array}$ \\
\hline & $\begin{array}{l}\text { Natural } \\
\text { heritage }\end{array}$ & $\begin{array}{l}\text { The concession site is located } 0,1 \mathrm{~km} \text { from the proposed natural } \\
\text { heritage, Machevo, monument of the nature. }\end{array}$ \\
\hline \multirow{2}{*}{ 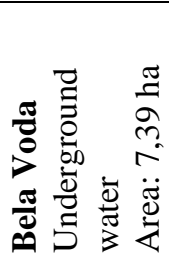 } & Surface water & $\begin{array}{l}\text { The River Bela Voda is passing by the concession site. } \\
\text { The Prevedenska River is passing by the concession site on a } 0,3 \mathrm{~km} \\
\text { distance. }\end{array}$ \\
\hline & $\begin{array}{l}\text { Natural } \\
\text { heritage }\end{array}$ & $\begin{array}{l}\text { The concession site is located in representative area Ograzden proposed } \\
\text { to be managed for species conservation. }\end{array}$ \\
\hline
\end{tabular}

Table 5. Spatial potential of the concession sites for geological research in municipality of Delchevo

\begin{tabular}{|c|c|c|}
\hline Research site & \multicolumn{2}{|r|}{ Spatial potential } \\
\hline \multirow{4}{*}{ 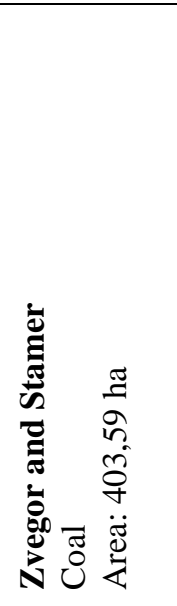 } & Populated area & $\begin{array}{l}\text { The concession site is located } 1,7 \mathrm{~km} \text { from Delchevo. } \\
\text { Planned gas line is passing through the concession site. }\end{array}$ \\
\hline & Surface water & $\begin{array}{l}\text { The Bregalnica River and some other small watercourses are passing } \\
\text { through the concession site. } \\
\text { Grashtica River is passing by near the concession site. } \\
\text { Irrigation system Delchevsko Pole is passing through the concession } \\
\text { site. } \\
\text { Water supply system Delchevo is passing through the concession site. } \\
\text { Wastewater system is passing on } 0,9 \mathrm{~km} \text { distance from the site. }\end{array}$ \\
\hline & $\begin{array}{l}\text { Natural } \\
\text { heritage }\end{array}$ & $\begin{array}{l}\text { The concession site is located } 0,4 \mathrm{~km} \text { from the proposed natural heritage } \\
\text { for protection, Stamer - natural rarity, } 1,6 \mathrm{~km} \text { from the Cave Konjsk } \\
\text { Dupka-monument of nature. } \\
\text { The concession site is located } 2 \mathrm{~km} \text { from the protected natural heritage } \\
\text { Zvegor - natural rarity. }\end{array}$ \\
\hline & Envirc & cated $0,7 \mathrm{~km}$ from the concession site. \\
\hline & Popula & $\begin{array}{l}\text { The } p \\
\text { Plann }\end{array}$ \\
\hline ت. & Surface & $\begin{array}{l}\text { The Bregalnica River and some other small watercourses are passing } \\
\text { through the concession site. } \\
\text { Irrigation system Delchevsko Pole is passing through the concession } \\
\text { site. } \\
\text { Water supply system Delchevo is passing at } 0,3 \mathrm{~km} \text { distance from the } \\
\text { concession site. } \\
\text { Wastewater system is passing at } 0,7 \mathrm{~km} \text { distance from the concession } \\
\text { site. }\end{array}$ \\
\hline$\underline{3}$ & & $\begin{array}{l}\text { The concession site is located } 2,4 \mathrm{~km} \text { from the proposed natural heritage } \\
\text { for protection, Stamer - natural rarity. }\end{array}$ \\
\hline
\end{tabular}




\begin{tabular}{|c|c|c|}
\hline \multirow{3}{*}{ 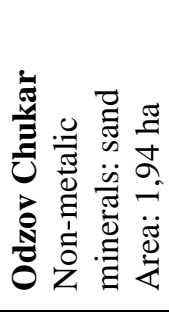 } & Populated area & $\begin{array}{l}\text { The nearest populated area Zvegor is located at } 0,4 \mathrm{~km} \text { distance from } \\
\text { the concession site. }\end{array}$ \\
\hline & Surface water & $\begin{array}{l}\text { The concession site is partially entering in the irrigation system } \\
\text { Sandanski. } \\
\text { The Gabrovska River is passing by the concession site on a } 0,5 \mathrm{~km} \\
\text { distance, and the river Zvegor is passing by on a } 0,6-0,7 \mathrm{~km} \text { distance. }\end{array}$ \\
\hline & $\begin{array}{l}\text { Natural } \\
\text { heritage }\end{array}$ & $\begin{array}{l}\text { The concession site is located at } 0,9 \mathrm{~km} \text { distance from the protected } \\
\text { natural heritage Zvegor - natural rarity. }\end{array}$ \\
\hline \multirow[b]{2}{*}{ 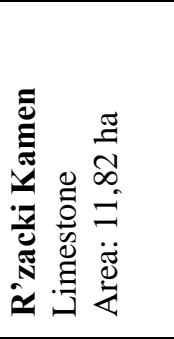 } & Populated area & $\begin{array}{l}\text { The nearest populated area Zvegor is located at } 2 \mathrm{~km} \text { distance from the } \\
\text { concession site. }\end{array}$ \\
\hline & $\begin{array}{l}\text { Natural } \\
\text { heritage }\end{array}$ & $\begin{array}{l}\text { The concession site is is located } 1,7 \mathrm{~km} \text { from the proposed natural } \\
\text { heritage for protection, Stamer - natural rarity. }\end{array}$ \\
\hline
\end{tabular}

Table 6. Spatial potential of the concession sites for geological research in municipality of Makedonska Kamenica

\begin{tabular}{|c|c|c|}
\hline \multirow{3}{*}{$\begin{array}{l}\text { Research } \\
\text { site }\end{array}$} & \multirow{2}{*}{\multicolumn{2}{|c|}{ Spatial potential }} \\
\hline & & \\
\hline & Populated area & \\
\hline \multirow{2}{*}{ 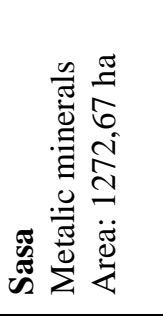 } & Surface water & $\begin{array}{l}\text { Kozja River, Svinja River, Petrova River and some other small } \\
\text { watercourses are passing through the concession site. } \\
\text { The Kamenica River is passing near by the concession site. }\end{array}$ \\
\hline & $\begin{array}{l}\text { Natural } \\
\text { heritage }\end{array}$ & $\begin{array}{l}\text { The concession site is entering the proposed natural heritage Osogovski } \\
\text { planini [5]. } \\
\text { The concession site is entering the proposed natural heritage Crvena } \\
\text { Reka. }\end{array}$ \\
\hline \multirow{3}{*}{ 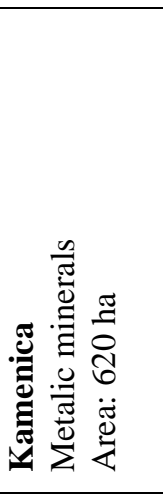 } & Popula & $\begin{array}{l}\text { The populated area Lukovica is entering the concession site. } \\
\text { Makedonska Kamenica is located on } 0,1 \mathrm{~km} \text { distance from the } \\
\text { concession site. }\end{array}$ \\
\hline & Surface water & $\begin{array}{l}\text { Kamenica, Lukovicka Reka and some other small watercourses are } \\
\text { passing through the concession site. } \\
\text { The planned irrigation system Lukovicka River is entering the } \\
\text { concession site. } \\
\text { The planned accumulation Lukovica is entering the concession site. } \\
\text { The concession site is located on } 0,7 \mathrm{~km} \text { distance from the protection } \\
\text { zone of the accumulation Kalimansko Ezero. }\end{array}$ \\
\hline & Envir & $\begin{array}{l}\text { There are installations near by the concession site that have had negative } \\
\text { environmental impact in the near past. }\end{array}$ \\
\hline
\end{tabular}




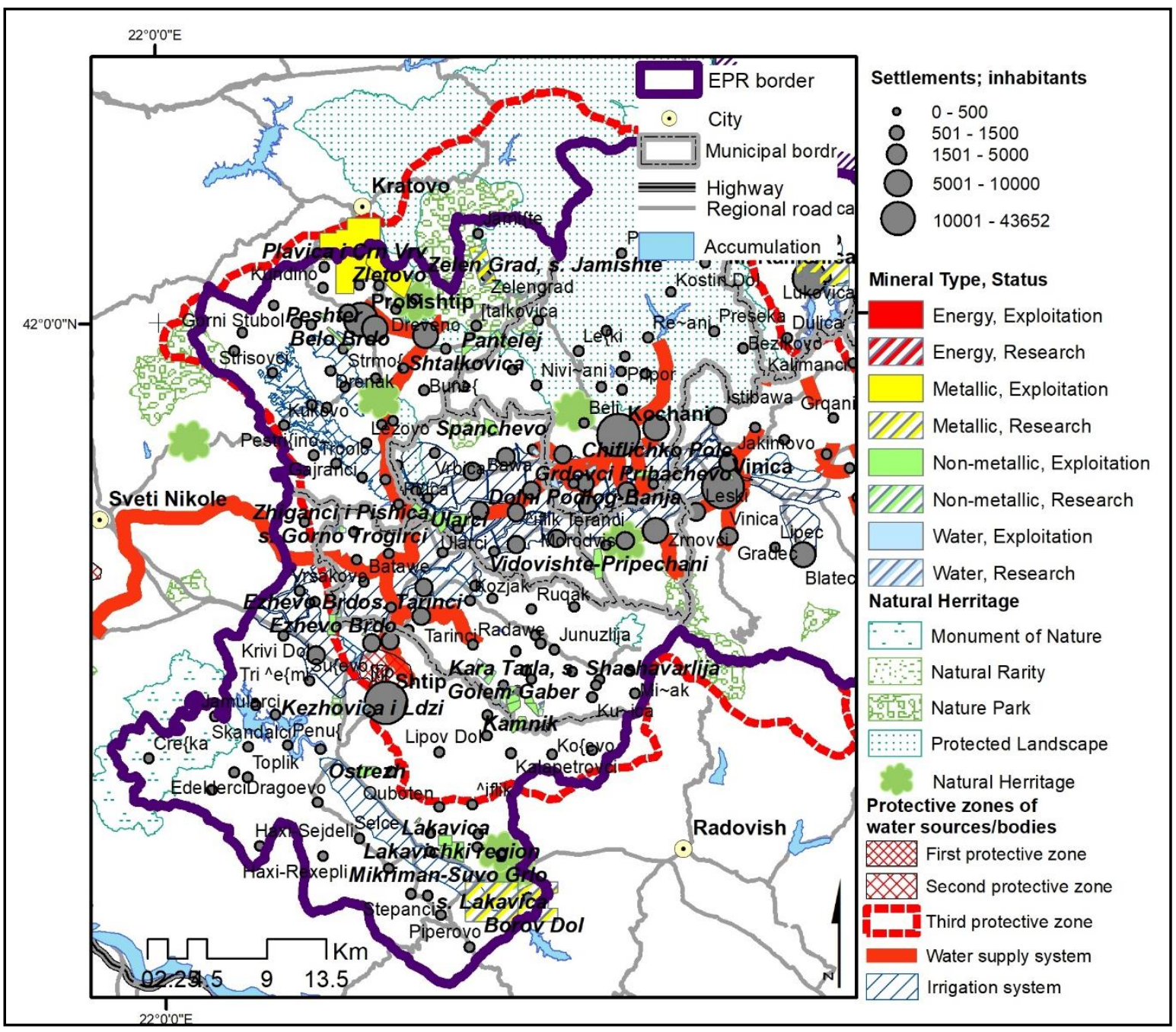

Figure 14. Localities with mining and research concessions in municipalities of Kochani, Zrnovci, Probishtip, Cheshinovo-Obleshevo, Karbinci and Shtip

Table 7. Spatial potential of the concession sites for geological research in municipality of Kocani

\begin{tabular}{|c|c|c|}
\hline $\begin{array}{l}\text { Research } \\
\text { site }\end{array}$ & \multicolumn{2}{|r|}{ Spatial potential } \\
\hline \multirow[b]{2}{*}{ 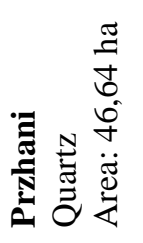 } & Surface water & $\begin{array}{l}\text { The concession site is entering in the third protection zone from the wells } \\
\text { in Stip. }\end{array}$ \\
\hline & $\begin{array}{l}\text { Natural } \\
\text { heritage }\end{array}$ & $\begin{array}{l}\text { The concession site is entering the proposed natural heritage Osogovski } \\
\text { planini. } \\
\text { The concession site is partially entering the proposed natural heritage and } \\
\text { Zletovska Reka - Ratkova Skala. }\end{array}$ \\
\hline \multirow{3}{*}{ 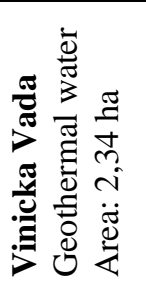 } & Populated area & Kochani is located on $1,1 \mathrm{~km}$ distance from the concession site. \\
\hline & Surface water & $\begin{array}{l}\text { The concession site is near by the Kochanska River. } \\
\text { The concession site is partially entering the planned water supply sistem } \\
\text { Kocani. } \\
\text { The concession site is entering in the third protection zone from the wells } \\
\text { in Stip. }\end{array}$ \\
\hline & Environment & Wild dump is located on $0,3 \mathrm{~km}$ from the concession site. \\
\hline
\end{tabular}


Table 8. Spatial potential of the concession sites for geological research in municipality of Probishtip

\begin{tabular}{|c|c|c|}
\hline $\begin{array}{l}\text { Research } \\
\text { site }\end{array}$ & \multicolumn{2}{|r|}{ Spatial potential } \\
\hline \multirow{3}{*}{ 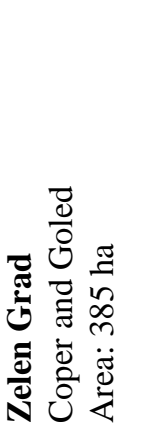 } & Populated area & $\begin{array}{l}\text { The populated area Zelen Grad is entering the concession site. } \\
\text { The concession site is located near by the populated area Jamishte. }\end{array}$ \\
\hline & Surface water & $\begin{array}{l}\text { The concession site is entering the firs and second protection zones of the } \\
\text { river Zletovica. } \\
\text { The concession site is entering in the third protection zone from the wells } \\
\text { in Stip. }\end{array}$ \\
\hline & $\begin{array}{l}\text { Natural } \\
\text { heritage }\end{array}$ & $\begin{array}{l}\text { The concession site is entering the proposed natural heritage Osogovski } \\
\text { planini. } \\
\text { The concession site is partially entering the proposed natural heritage and } \\
\text { Zletovska Reka - Ratkova Skala. }\end{array}$ \\
\hline
\end{tabular}

Table 9. Spatial potential of the concession sites for geological research in municipality of Karbinci

\begin{tabular}{|c|c|c|}
\hline Research site & \multicolumn{2}{|r|}{ Spatial potential } \\
\hline \multirow{3}{*}{ 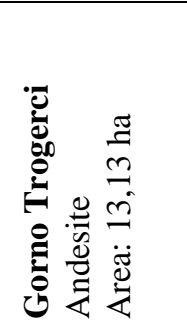 } & $\begin{array}{l}\text { Populated } \\
\text { area }\end{array}$ & $\begin{array}{l}\text { The nearest populated area Gorno Trogerci is located on } 1 \mathrm{~km} \text { distance } \\
\text { from the concession site. }\end{array}$ \\
\hline & $\begin{array}{l}\text { Surface } \\
\text { water }\end{array}$ & $\begin{array}{l}\text { The concession site is entering in the third protection zone from the wells } \\
\text { in Stip. } \\
\text { The concession site is located on a } 2 \mathrm{~km} \text { distance from the planned water } \\
\text { supply system Varshakovo. }\end{array}$ \\
\hline & $\begin{array}{l}\text { Natural } \\
\text { heritage }\end{array}$ & $\begin{array}{l}\text { The concession site is entering in the proposed natural heritage for } \\
\text { protection-Mangovica [5]. }\end{array}$ \\
\hline \multirow[b]{2}{*}{ 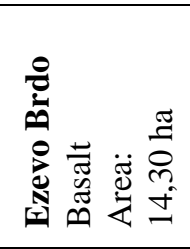 } & $\begin{array}{l}\text { Populated } \\
\text { area }\end{array}$ & $\begin{array}{l}\text { The nearest populated area Sarcievo is located on } 2 \mathrm{~km} \text { distance from the } \\
\text { concession site. }\end{array}$ \\
\hline & $\begin{array}{l}\text { Surface } \\
\text { water }\end{array}$ & $\begin{array}{l}\text { The concession site is entering in the third protection zone from the wells } \\
\text { in Stip. } \\
\text { The concession site is located on a } 0,3 \mathrm{~km} \text { distance from the planned water } \\
\text { supply sistem Balvan. }\end{array}$ \\
\hline \multirow{3}{*}{ 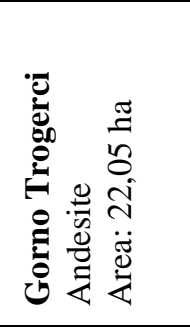 } & $\begin{array}{l}\text { Populated } \\
\text { area }\end{array}$ & $\begin{array}{l}\text { The nearest populated area Gorno Trogerci is located on } 0,4 \mathrm{~km} \text { distance } \\
\text { from the concession site. }\end{array}$ \\
\hline & $\begin{array}{l}\text { Surface } \\
\text { water }\end{array}$ & $\begin{array}{l}\text { The concession site is entering in the third protection zone from the wells } \\
\text { in Stip. } \\
\text { The concession site is located on a } 2 \mathrm{~km} \text { distance from the planned water } \\
\text { supply sistem Varshakovo. }\end{array}$ \\
\hline & $\begin{array}{l}\text { Natural } \\
\text { heritage }\end{array}$ & $\begin{array}{l}\text { The concession site is entering in the proposed natural heritage for } \\
\text { protection-Mangovica [5]. }\end{array}$ \\
\hline \multirow[b]{2}{*}{ 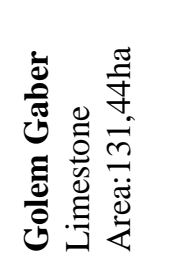 } & $\begin{array}{l}\text { Populated } \\
\text { area }\end{array}$ & $\begin{array}{l}\text { The concession site is near by the populated areas Golem Gaber and Mal } \\
\text { Gaber. }\end{array}$ \\
\hline & $\begin{array}{l}\text { Surface } \\
\text { water }\end{array}$ & A watercourse is entering in the concession site. \\
\hline \multirow[b]{2}{*}{ 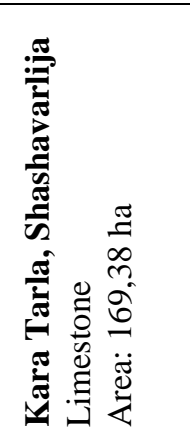 } & $\begin{array}{l}\text { Populated } \\
\text { area }\end{array}$ & $\begin{array}{l}\text { The nearest populated area Radanje and Golem Gaber are located on } 0,8 \\
k m \text { distance from the concession site. }\end{array}$ \\
\hline & $\begin{array}{l}\text { Surface } \\
\text { water }\end{array}$ & $\begin{array}{l}\text { The concession site is located near the Radanjska River. } \\
\text { The concession site is entering in the third protection zone from the wells } \\
\text { in Stip. } \\
\text { The concession site is located on } 1,5 \mathrm{~km} \text { southeast from the water supply } \\
\text { sistem Vinica Stip. }\end{array}$ \\
\hline
\end{tabular}




\begin{tabular}{|l|l|l|}
\hline Research site & \multicolumn{1}{|c|}{ Spatial potential } \\
\hline \multirow{2}{*}{} & $\begin{array}{l}\text { Populated } \\
\text { area }\end{array}$ & $\begin{array}{l}\text { The populated area Tarinci is located on } 0,2 \mathrm{~km} \text { distance from the } \\
\text { concession site. } \\
\text { The populated area Karbinci is located on 0,6 km distance from the } \\
\text { concession site. }\end{array}$ \\
\cline { 2 - 3 } & $\begin{array}{l}\text { Surface } \\
\text { water }\end{array}$ & $\begin{array}{l}\text { The concession site is located on 0,4 km distance from Bregalnica River. } \\
\text { The concession site is partially entering the planned water supply sistem } \\
\text { Karaorman. } \\
\text { The concession site is located on a } 0,6 \mathrm{~km} \text { distance from the planned } \\
\text { irrigation system Argulica. } \\
\text { The concession site is entering in the third protection zone from the wells } \\
\text { in Stip. }\end{array}$ \\
\hline
\end{tabular}

Table 10. Spatial potential of the concession sites for geological research in municipality of Shtip

\begin{tabular}{|c|c|c|}
\hline $\begin{array}{l}\text { Research } \\
\text { site }\end{array}$ & \multicolumn{2}{|r|}{ Spatial potential } \\
\hline \multirow{3}{*}{ 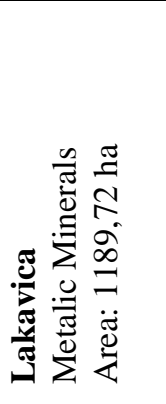 } & $\begin{array}{l}\text { Populated } \\
\text { area }\end{array}$ & $\begin{array}{l}\text { The populated area Novo Selo is entering the concession site. } \\
\text { The concession site is located on } 1,5 \mathrm{~km} \text { distance from the populated areas } \\
\text { Piperovo and Leskovica. }\end{array}$ \\
\hline & $\begin{array}{l}\text { Surface } \\
\text { water }\end{array}$ & $\begin{array}{l}\text { Some small watercourses, wich later on are entering in the Mantovo } \\
\text { accumulation, are passing through the concession site. } \\
\text { The concession site is located on } 1 \mathrm{~km} \text { distance from the accumulation } \\
\text { Mantovo. } \\
\text { The concession site is entering the water supply sistem Lakavica. }\end{array}$ \\
\hline & $\begin{array}{l}\text { Natural } \\
\text { heritage }\end{array}$ & $\begin{array}{l}\text { The concession site is located on a } 0,6 \mathrm{~km} \text { distance from the proposed } \\
\text { natural heritage Pilav Tepe [5]. }\end{array}$ \\
\hline \multirow{3}{*}{ 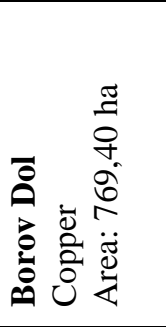 } & $\begin{array}{l}\text { Populated } \\
\text { area }\end{array}$ & $\begin{array}{l}\text { The concession site is located on 0,5 km distance from the populated areas } \\
\text { Dolna Vrashtica, Gorna Vrashtica, Damjan and Novo Selo. }\end{array}$ \\
\hline & $\begin{array}{l}\text { Surface } \\
\text { water }\end{array}$ & $\begin{array}{l}\text { Some small watercourses, wich later on are entering in the Mantovo } \\
\text { accumulation, are passing through the concession site. } \\
\text { The concession site is located on } 0,4 \mathrm{~km} \text { distance from the accumulation } \\
\text { Mantovo. }\end{array}$ \\
\hline & $\begin{array}{l}\text { Natural } \\
\text { heritage }\end{array}$ & $\begin{array}{l}\text { The concession site is located on a } 1,3 \mathrm{~km} \text { distance from the proposed } \\
\text { natural heritage Pilav Tepe [5]. }\end{array}$ \\
\hline \multirow[b]{2}{*}{ 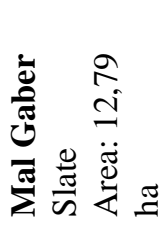 } & $\begin{array}{l}\text { Populated } \\
\text { area }\end{array}$ & $\begin{array}{l}\text { The concession site is located on } 1,7 \mathrm{~km} \text { distance from the nearest } \\
\text { populated area Mal Gaber. }\end{array}$ \\
\hline & $\begin{array}{l}\text { Surface } \\
\text { water }\end{array}$ & $\begin{array}{l}\text { Small watercourse is passing by the concession site. } \\
\text { The concession site is entering in the third protection zone from the wells } \\
\text { in Stip. }\end{array}$ \\
\hline \multirow[b]{2}{*}{ 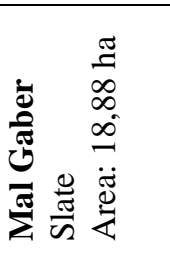 } & $\begin{array}{l}\text { Populated } \\
\text { area }\end{array}$ & $\begin{array}{l}\text { The concession site is located on } 2 \mathrm{~km} \text { distance from the nearest populated } \\
\text { area Mal Gaber. }\end{array}$ \\
\hline & $\begin{array}{l}\text { Surface } \\
\text { water }\end{array}$ & $\begin{array}{l}\text { Small watercourse is passing by the concession site. } \\
\text { The concession site is entering in the third protection zone from the wells } \\
\text { in Stip. }\end{array}$ \\
\hline
\end{tabular}

Regarding the information from the available literature used for preparation of this paper, there were no existing concession sites for geological research in municipalities of Cheshinovo-Obleshevo, Pehcevo, Vinica and Zrnovci [11]. 


\section{CONCLUSIONS}

The overall analysis shows that when issuing concessions for exploitation (and research) of minerals, priority, if not exclusivity, is given to the economy. Environmental issues and impact on the health of the people living in the areas where mining is to be present are not well elaborated. This should be changed especially if we have in mind the trends present in the EU.

Over several decades the EU's coal mining activity has been in decline due to competition from coal imports and the substitution of other fuels to produce electricity, the latter stimulated in part by efforts to reduce emissions [9].

The experience from mining of metallic minerals in other countries shows that even in very small amounts, metals can be toxic to humans and wildlife. Metals are particularly problematic because they do not break down in the environment. They settle to the bottom and persist in the stream for long periods of time, providing a long-term source of contamination to the aquatic insects that live there, and the fish that feed on them. Carried in water, the metals can travel far, contaminating streams and groundwater for great distances. The impacts to aquatic life may range from immediate fish kills to sublethal, impacts affecting growth, behaviour or the ability to reproduce [4].

The mining activities in the protected areas or areas proposed for protection will irreversibly affect the landscape diversity and may result in loss of sceneries of great importance. They are noted as risks to natural heritage in the National Strategy for heritage protection, as well [12]. It should be noted that IUCN's members adopted a recommendation at the World Conservation Congress in Amman, Jordan in October 2000, which suggested that mining should not take place in IUCN category I-IV protected areas. Recommendation 2.82 includes a section that: "State members to prohibit by law, all exploration and extraction of mineral resources in protected areas corresponding to IUCN protected area management categories I-IV". The recommendation also includes a paragraph relating to category $\mathrm{V}$ and VI protected areas: "in categories V and VI, exploration and localized extraction would be accepted only where the nature and extent of the proposed activities of the mining project indicate the compatibility of the project activities with the objectives of the protected areas" [10]. Republic of Macedonia, as a country member in the IUCN, should review these recommendations and implement them in the national legislation.

There are several examples in the EPR where the concession sites intersect with the limits of the settlements. Also, there are many watercourses which are entering different concession sites.

The contemporary approach would consist of several measures:

- Modernization of existing technologies and strict emission control in active mines;

- Economic vs environmental, with the emphasis on the health Estimate of the overall effect of the population prior to issuing concessions for opening of new mines;

- Choosing priorities in a strategy for development at the state level based on the principles of sustainable development and strengthening the role of spatial planning and strategic assessment of the impact on the environment.

\section{REFERENCES}

[1] Spatial Planning Agency. Spatial Plan of the East Planning Region of the Republic of Macedonia, Draft Plan, Republic of Macedonia, 2017, pp 8-9; 44-50

[2] State Statistical Office. Environmental statistics, Republic of Macedonia, 2017 
[3] Ministry of environment and physical planning. National environmental indicators available at: http://www.moepp.gov.mk/?page_id=746

[4] Guidebook for Evaluating Mining Project EIAs: Overview of Mining and its Impacts.

[5] MES. "Development of a representative network of protected areas", Project 00058373 - PIMS 3728, "Strengthening the ecological, institutional and financial sustainability of the system of protected areas in the Republic of Macedonia", 2010

[6] Ministry of environment and physical planning. Capacity building for implementation of the EU Directive on landfills - closure of non-standard ones landfills and inspections, Skopje, 2011, pp. 29

[7] State Statistical Office. Regional statistics, Republic of Macedonia, 2015

[8] Decision for determination of nomenclature of territorial units for statistics. Official Gazette No. 158/07, 63/2007

[9] Eurostat. Statistic explained. Mining and quarrying statistics, 2017 available at http://ec.europa.eu/eurostat/statistics-explained/index.php/Mining_and_quarrying_statistics_-

_NACE_Rev._2

[10] IUCN. Guidelines for Applying Protected Area Management Categories. Gland, Switzerland: Dudley, N. (Editor), 2008, pp.12-13

[11] GIM. Mineral raw materials and exploitation of mineral raw materials in the Bregalnica basin. Skopje, 2016

[12] National strategy for nature protection (2017-2027). Official Gazette No. 50/2018

[13]http://makstat.stat.gov.mk/PXWeb/pxweb/mk/MakStat/MakStat_ZivotnaSredina/375_ ZivSr_reg_otp_BCG_mk.px/table/tableViewLayout2/?rxid=46ee0f64-2992-4b45-a2d9cb4e5f7ec5ef, visited March 2018 